\title{
A FONOLÓGIAI TUDATOSSÁG FEJLŐDÉSE ÉS SZÖVEGÉRTÉSSEL VALÓ KAPCSOLATA AZ ÁLTALÁNOS ISKOLA ELSŐ NÉGY ÉVFOLYAMÁN A SZOCIOÖKONÓMIAI STÁTUSZ TÜKRÉBEN
}

\author{
TÖRÖK TÍMEA ${ }^{1}$ - HÓDI ÁGNES ${ }^{2}$ \\ ${ }^{1}$ Szegedi Tudományegyetem Neveléstudományi Doktori Iskola \\ ${ }^{2}$ MTA-SZTE Képességfejlődés Kutatócsoport \\ e-mail: torokt@edu.u-szeged.hu; agnes.hodi@edu.u-szeged.hu
}

Beérkezett: 2014. december 06. - Elfogadva: 2015. június 27.

\begin{abstract}
Az elmúlt évtizedekben számos külföldi kutatás mutatott rá a fonológiai tudatosság olvasásban betöltött kiemelt szerepére. A vizsgálatok többsége az olvasási teljesítményt a szóolvasással, dekódolással jellemezte, kevesebb figyelem irányult e metanyelvi készség szövegértésben betöltött szerepére. Azon kevés angol nyelvterületen végzett empirikus vizsgálat, amely a fonológiai tudatosság szövegértésben betöltött szerepét tárta fel, hosszabb időn keresztül fennálló együttjárást mutatott a két változó között. Jól ismert tény, hogy a magyar diákok szövegértési teljesítményének egyik befolyásoló tényezője a család szocioökonómiai státusza (SES). A legtöbb nemzetközi vizsgálati eredmény szerint a SES meghatározó szerepet tölt be a fonológiai tudatosság alakulásában is, de hazai kontextusban még nem vizsgálták e kapcsolatrendszert. Jelen tanulmány célja a fonológiai tudatosság fejlödésének és szövegértéssel való kapcsolatának vizsgálata a SES tükrében az általános iskola elsö négy évfolyamán.

A vizsgálatban egy általános iskola alsó tagozatos tanulói vettek részt $(N=205)$. A tanulók egy online fonológiai tudatosságot, egy szövegértést mérö tesztet és egy papír-ceruza alapú háttérkérdöivet töltöttek ki.

A fonológiai tudatosság fejlettségi szintjében szignifikáns változás második és harmadik évfolyam között történt. A teljesítmény a negyedik évfolyamon sem érte el a maximumot. Adataink szerint a SES mind a fonológiai tudatossággal, mind a szövegértéssel szignifikáns kapcsolatot mutatott. A három változó közötti kapcsolatrendszert feltáró modell szerint a SES meghatározza a fonológiai tudatosság és a szövegértés alakulását egyaránt, és e két kognitív változó között kölcsönös kapcsolat áll fenn.

Tanulmányunk felhirvja a figyelmet a fonológiai tudatosság fejlesztésének fontosságára az olvasástanulás időszakában, valamint az otthoni környezetböl fakadó hátrányok időben történő kompenzálására, megteremtve ezzel a tanulók szövegértési teljesítménye javulásának és sikeresebb iskolai pályafutásának lehetöségét.
\end{abstract}

Kulcsszavak: fonológiai tudatosság, szövegértés, szocioökonómiai státusz 


\section{BEVEZETÉS}

Az olvasáselsajátítás hosszú és összetett folyamat. Ha „bármelyik összetevő fejlődése megkésik, megreked, akkor az gátat jelent a többi összetevő fejlődéséhez is, kihat az olvasásképességre (szövegértésre)", így a szövegértéshez minden egyes összetevő optimális fejlettségi szintjének elérése szükséges (JózSA és STEKLÁCS, 2009, 367). A fonológiai tudatosság az olvasáshoz kapcsolható kognitív feldolgozási folyamatok közül a leginkább tanulmányozott entitás (BLOMERT és CsÉPE, 2012). E metanyelvi készség nemcsak a későbbi olvasás, illetve szövegértési képesség alakulásának fontos és megbízható előrejelzője, de kulcsszerepet játszik a korai olvasáselsajátításban is (például OuleTte és HALEY, 2013; SHANAHAN, 2012).

A kutatók többsége a fonológiai tudatosságot, azaz a szavakon belüli fonológiai egységek hozzáférésének, azonosításának képességét és az ezekkel történő műveletek végzését (EHRI és mtsai, 2001; SÉnÉchal, Ouellette és YounG, 2004) gyűjtőfogalomnak tekinti (CséPe, 2006; GoswAMI és Bryant, 1990). GosWAMI és BRYANT (1990) szerint legalább háromféle módja van annak, hogy egy szót hangokra bontsunk, s ennek megfelelően a fonológiai tudatosság három lehetséges formáját különbözteti meg: 1. a szótagszintű, 2. a fonémaszintű, valamint egy úgynevezett közbülső, szótagon belüli fonológiai tudatosságot, azaz a szótag onsetrime szerkezetére vonatkozó tudatosságot. Továbbá a fonématudatosság részeként, kezdetleges fonológiai feldolgozási készségként tartják számon a rímek felismerését is (ANTHONY és FRANCIS, 2005; GOSWAMI és BRYANT, 1990). Ennek ellenére a területen folytatott empirikus kutatások nagy változatosságot mutatnak a fonológiai tudatosság konstruktumának definiálásában. Néhányan a mérni kívánt területet egyfaktoros, mások kétfaktoros, s megint mások, például GoswAMI és BRYANT (1990) elképzelésével összhangban, három faktorból álló struktúraként kezelik (KJeldsen, KÄRnÄ, Niemi, OlOfSSOn és WitTing, 2014).

A fonológiai tudatosságra fókuszáló kutatások többsége az olvasás-szövegértés mechanizmusában próbálja meghatározni e metanyelvi készség szerepét, hatását. A fonológiai tudatosság és az olvasás kapcsolatát feltáró kutatások többsége az olvasási teljesítményt a szóolvasással, dekódolással jellemezte, kevesebb figyelem irányult a tudatosságnak a szövegértésben betöltött szerepére. Egy empirikus vizsgálat, amely a szövegértéssel való kapcsolatát tárta fel, összefüggést mutatott a két változó között. A fonológiai tudatosság magyarázó erővel bírt a szövegértési teljesítményre, és ez a hatás az idő előrehaladtával is megmaradt (NATION és SNOWLING, 2004).

Jóval kevesebb vizsgálat vállalkozott arra, hogy a fonológiai tudatosság fejlődését, illetve fejlettségi szintjét befolyásoló háttérváltozókat vegye górcső alá. Az e területen végzett vizsgálatok olyan nyelvi (például ortográfia), kognitív (például szókincs, betűismeret: OuletTE és HALEY, 2013), ökológiai (például szocioökonómiai státusz - SES: MCDOWELL, LONIGAN és GOLDSTEIn, 2007) és környezeti komponenseket, tényezőket (például szülő-gyermek otthoni környezetben zajló interakció: WOOD, 2002; a formális írás-olvasástanítás hatása: SKIBBE, GRIMM, BOWLES, és MORRISON, 2012) vontak be, amelyek meghatározó szerepet tölthetnek be a fonológiai tudatosság alakulásában. 
A legtöbb nemzetközi vizsgálati eredmény szerint a szocioökonómiai státusz meghatározó szerepet tölt be a fonológiai tudatosság alakulásában. Hazai vizsgálatok adatai azt mutatják, hogy a szocioökonómiai státusz erősen meghatározza a legtöbb kognitív képesség, kompetencia, valamint tantárgyi teljesítmény alakulását. Nemzetközi és hazai keresztmetszeti nagymintás olvasásmérések (lásd OECD PISA, IEA PIRLS, Szegedi Longitudinális Iskolai Program, OKM) adatai rendre azt mutatják, hogy a tanulók szövegértését befolyásolja a SES, azonban hazai kutatások nem tárták még fel azt, hogy a szövegértést és annak egyik alapvető komponensét (lásd NAGY, 2006), hogyan és milyen mértékben befolyásolja ezen háttérváltozó.

A metanyelvi készségek közül a fonológiai tudatosság hazánkban az egyik legszélesebb körben vizsgált terület (lásd TóTH, 2012; JORDANIDISZ, 2009). Az eddigi kutatások alapján számos további kérdés vár megválaszolásra az egyes területek fejlődési ívét tekintve, különösen az általános iskola 1-4. évfolyamán. A fonológiai feldolgozás az olvasás egyik fő építőköve, mindazonáltal magyar anyanyelvủ tanulók körében még nem térképezték fel a fonológiai tudatosság szövegértésben betöltött szerepét, mindamellett, hogy ez a kutatási cél nemzetközi viszonylatban is alulreprezentált.

A fentiek figyelembevételével hazai és külföldi irodalomra, illetve empirikus vizsgálatok eredményeire támaszkodva tủztük ki célul a fonológiai tudatosság és szövegértéssel való kapcsolatának vizsgálatát magyar anyanyelvủ általános iskolás tanulók körében az olvasástanulás időszakában. További célként tűztük ki annak feltárását, hogy a tanulók szocioökonómiai státusza milyen mértékben befolyásolja a kognitív alapkészség, valamint a szövegértés fejlettségét.

\section{A KUTATÁS ELMÉLETI HÁTTERE}

\section{A fonológiai tudatosság fejlődése}

A fonológiai tudatosság fejlődése során fokozatokat, szinteket állapíthatunk meg. A fejlődés jellemezhetố a nyelvi egységek mérete mentén. Elöbb a nagyobb nyelvi egységek (lásd szótagok) tudatossága, majd később a kisebb fonológiai egységek (lásd fonémák) iránti szenzitivitás és manipulációs készség jelenik meg (CARROLL, SNOWling, Hulme és Stevenson, 2003; Ziegler és Goswami, 2005).

Bár eltérő a terminológiai rendszer, a fonématudatosságot megtaláljuk NAGY József (2006) az olvasásképesség mint pszichikus rendszerről alkotott átfogó modelljében is. A modellben az olvasáskészség (olvasástechnika) egyik meghatározó komponenseként, szintén helyet kap az implicit és explicit szinten működő ún. beszédhanghallás. Előbbit beszédhang-felismerésnek, utóbbit beszédhang-kiemelésnek vagy beszédhang-tudatosságnak nevezi (NAGY, 2006). JózSA és STEKLÁCS (2009) szerint ez utóbbi maga a fonológiai tudatosság, azonban a beszédhanghallás egyértelműen kizárólag a fonémák szintjén értelmezendő, míg a fonológiai tudatosságot NAGY József (2006) munkája is egy tágabb, a szótagoló készséget is magában foglaló készségként említi. 
A fonológiai tudatosság fejlődésének kezdete az óvodáskorra tehető, míg a további szintje az olvasástanulással jelenik meg. A szótagszintű tudatosság már az iskola előtti időszakban kialakul, míg a fonématudatosság az általános iskola első és második évfolyamán jelenik meg a betűk és a betű-hang megfeleltetési szabályok elsajátítása révén (BLOMERT és CsÉPE, 2012).

A kutatási eredmények szerint a fonológiai tudatosságnak létezik egy univerzális, minden nyelvben detektálható fejlődési menete: 1. szótagszegmentálás és -szintézis, 2. rímfelismerés, 3. szótagmanipuláció (például szótagok törlése, cseréje), 4. fonémaazonosítás, 5 . fonémaszegmentálás és -szintézis és 6 . fonémamanipuláció (például fonémák törlése, cseréje, illetve azok sorrendjének megfordítása) (ANTHONY és FrANCIS, 2005). Azonban a nyelvek eltérő sajátosságai miatt a fonológiai tudatosság fejlődésén belül az egyes szintek megjelenésének ideje eltérhet (DUNCAN, 2010).

A hazai kutatók közül eddig kevesen vizsgálták a fonológiai tudatosság fejlődését. A fonológiai tudatosság területei közül KASSAI (1999) a szótagtudatosság fejlődésére helyezte a hangsúlyt. Nagycsoportos óvodásokat vont be a vizsgálatába, és ugyanezen populáció fejlődését az első osztályban is követte. Eredményei szerint a kevésbé jól teljesítők aránya lecsökken az első évfolyam végére, s ezt a tendenciát az olvasástanulás pozitív hatásával magyarázza. JORDANIDISz (2009) vizsgálatának a célja az volt, hogy feltárja, miként fejlődik a fonológiai tudatosság a magyar gyerekeknél az olvasástanulás kezdeti időszakában. A fonológiai tudatosság egyes területei fejlődésének követésére irányuló vizsgálatát első évfolyamos gyermekek körében végezte. Az előteszt adatai szerint az iskolába lépéskor, a tanév elején a tanulók a szótagszintézisre irányuló feladatokon teljesítettek a legjobban, ezt követte a szótagelhagyás, a beszédhang-izolálás, a szókezdő beszédhang-hangcsoport leválasztás, a beszédhang-szegmentálás, a beszédhangszintézis a rímkeresés, hoszszúbeszédhang-azonosítás. A tanulók a leggyengébb eredményt beszédhang-manipuláció területén nyújtották. Adatai arra engednek következtetni, hogy a magyar gyerekek fonológiai tudatosságának fejlődése a szótagokkal kezdődik, s a rím később jelenik meg. A többi nyelvhez hasonlóan a fonémaszint az, amely csak az olvasástanulás hatására jelenik meg.

\section{A fonológiai tudatosság és az olvasás kapcsolata}

A fonológiai tudatosság és az olvasás kapcsolatának vizsgálatát számos kutatás tűzte már ki célul, azonban a két változó pontos kapcsolata még nem tisztázott. VLOEDGRAVEN (2008) összegzése szerint három nézet körvonalazódik az eddigi kutatások alapján. Az egyik, hogy a fonológiai tudatosság az olvasástanulás előfeltétele. A másik vélemény szerint a fonológiai tudatosság az olvasástanulás következménye, fokozatosan alakul ki az olvasás-írás elsajátítása során - erre az összefüggésre az írni-olvasni nem tudó felnőttekkel folytatott vizsgálatok is rámutattak. A harmadik nézet szerint a két változó között kölcsönös a viszony, azaz a fonológiai tudatosság kezdeti szintjei támogatják az olvasás fejlődését, és az olvasáskészségek fejlettségei befolyással bírhatnak a fejlettebb tudatossági szintekre, például 
fonématudatosság, de az alapokhoz szükséges bizonyos szintű nyelvi tudatosság. Ezen elméletek között teremt kapcsolatot BLOMERT és CSÉPE (2012) a fonológiai tudatosság szintjei alapján nyújtott összegzése, miszerint a „beszédhangok szintjéhez való hozzáférés, azaz a fonématudatosság, eltérően a nagyobb hangegységektől, mint amilyenek a szótagok, az írni és olvasni tudás elsajátításához köthető, azaz csak annak kezdete után jelenik meg (BLOMERT és Csépe, 2012, 22). Mindazonáltal létezik egy negyedik, a nyelvelsajátítás kognitív szempontú interakcionalista magyarázatával összhangban lévő álláspont is, amely szerint „mind a nyelvi tudatosság, mind az olvasástanulás egy harmadik, kognitív tényezőtől függ: megfelelő szellemi érettségtől és intelligenciától” (ADAMIKNÉ JÁSzó, 2003, 37).

Széles körű egyetértés mutatkozik azonban abban, hogy a fonológiai tudatosság fejlettségi szintje megbízható előrejelzője a későbbi olvasásteljesítménynek (például CséPe, 2006; KJELdSEn, KÄRNÄ, Niemi, OlofsSOn és WitTing, 2014; FURNes és SAMUELSSON, 2011). Jól megalapozott elméletek és empirikus tanulmányok mutatnak rá a fonématudatosság dekódolással és pontos olvasással való kapcsolatára. A fonológiai tudatosság a pontos olvasást a fonológiai dekódolás fejlődésére gyakorolt hatásán keresztül befolyásolja (PHILlips és TORGESEN, 2006). A fonológiai tudatosság olvasás-szövegértésben betöltött szerepének vizsgálata kapcsán azonban GOSWAMI és BRYANT (1990) felhívja a figyelmet arra, hogy maga a tény, hogy az egyes betűk hangokat képviselnek, nem feltétlenül jelenti azt, hogy a gyermekek például a „kar” szót úgy tanulják meg elolvasni, hogy először megfejtik az egyes betűkhöz kapcsolódó hangokat, majd összeillesztik őket. Például egy lehetséges alternatívaként tartják számon azt, hogy a gyermek vizuális mintaként ismeri fel a szót anélkül, hogy különösebb energiát fektetne a betủ és hangok kapcsolatrendszerére, illetve támaszkodna a fonológiai tudatosságra. Ez az álláspont az olvasástanítás módszertanára lefordítva az 1980-as években domináns, holisztikus szemléletű, egész nyelvi módszerben (whole language approach) teljesedett ki.

A nyelvközi vizsgálatok eredményei azt bizonyítják, hogy a két változó között nyelvtől független kapcsolat áll fenn. ZIEGLER és munkatársai (2010) kutatásukban öt ország második osztályos tanulóit vizsgálták, köztük magyar diákokat is. A kutatás legfőbb kérdése az volt, hogy az egyes nyelvek esetében a fonológiai tudatosság, a gyors automatikus megnevezés, a nonverbális intelligencia és a szókincs milyen mértékben magyarázza a szóolvasási teljesítmény alakulását. Ezek közül a változók közül a fonológiai tudatosság volt az, amely leginkább összefüggött az olvasás és a dekódolás sebességével és pontosságával. Az eredmények alapján arra a következtetésre jutottak, hogy minden ortográfiai típusú nyelv olvasástanulásához szükséges a fonológiai tudatosság, de hatásának mértéke a nyelv konzisztenciájának mentén eltérő.

E kutatáshoz hasonlóan VAESSEN és munkatársai (2010) magyar, holland, portugál tanulókat vizsgáltak elsőtől negyedik évfolyamig. A vizsgálat célja az volt, hogy feltárja - többek között - a fonológiai tudatosság alakulását különböző ortográfiájú nyelvek esetében és ezek milyen szerepet játszanak a szóolvasási teljesítményben. Eredményeik alapján szignifikáns különbség mutatkozott az egyes évfolyamok között a fonológiai tudatosságot tekintve. Feltehetőleg folyamatosan fejlő- 
dik ebben az időszakban, de nem éri el a befejező szintet, viszont az olvasási teljesítményben játszott szerepe fokozatosan csökken. A kutatók szerint ennek hátterében az állhat, hogy a nyelv jellemzői mellett a mérési módszer is befolyásolja azt, hogy kimutatható-e a kapcsolat a tudatosság és az olvasás között. Fontos megemlíteni azonban, hogy a fonológiai tudatosság fejlődése és olvasás közötti kapcsolat alakulására az olvasástanulás módszere is jelentős hatással bír (JORDANIDIsz, 2009).

A kapcsolatot feltáró vizsgálatok többsége a szóolvasással való viszonyt tárja fel, kevesebb figyelem irányul a fonológiai tudatosság és a szövegértés kapcsolatára. NATION és SNOWLING (2004) a szövegértéssel való kapcsolatot vizsgálták egy longitudinális vizsgálat keretei között. Eredményeik szerint a szóolvasás mellett a szövegértéshez is hozzájárul a fonológiai tudatosság. KJELDSEN és munkatársai (2014) egy óvodai fonológiai tudatosság fejlesztőprogram hatását vizsgáló kutatásukban 209 svéd anyanyelvű gyermek teljesítményének alakulását követték nyomon a kilencedik évfolyam végéig. Adataik a fenti kutatások eredményeivel összhangban alátámasztják a fonológiai tudatosság és szövegértés közötti összhangot és rámutatnak a korai fejlesztés fontosságára.

Hazai kontextusban JORDANIDISZ (2009) vizsgálta a fonológiai tudatosság fejlődése és az olvasás közötti kapcsolatot egy követéses vizsgálat keretében. Olvasás mérőeszköze az olvasás különböző területeiről, szintjeiről, valamint a tanulók szövegértéséről gyűjtött adatokat. A kapott eredmények szerint megállapítható, hogy első osztályban az év elején mutatott fonológiai tudatosság teljesítmény közepes korrelációt mutat az év végi olvasásteljesítménnyel. Tanulmányából azonban nem lehet egyértelmű következtetéseket levonni a fonológiai tudatosság és szövegértés kapcsolatának alakulásáról, mert az olvasásteszt eredményeit, illetve a fonológiai tudatossággal való kapcsolatát szubtesztenként nem vizsgálta, így e komponens értő olvasásra gyakorolt hatása nem tisztázott.

Az eddigieket összegezve az 1. ábra áttekinthető formában mutatja be a fonológiai tudatosság szövegértésben játszott szerepét az olvasástanulás időszaka alatt. Jól látható, hogy e metanyelvi készség közvetlen és közvetett módon (a szóolvasó készségen keresztül) egyaránt hozzájárul az értő olvasás alakulásához. Természetesen a fonológiai tudatosság mellett az iskolakezdés időszakára elsajátított szókincs is szerepet játszik a szövegértés alakulásában direkt vagy indirekt módon. A szókincs és fonológiai tudatosság kölcsönös kapcsolata a szavak fonológiai szerkezetének mentális reprezentációjában ragadható meg leginkább. A nyelvi fejlődés során folyamatosan gyarapodó szókincs kritikus eszköze ezen reprezentációk fejlesztésének, amelyek pedig kulcsfontosságúak a fonológiai tudatosság hatékony fejlődésében és a további szókincsnövekedésben. A korai olvasási készségek, mint a betűzés, korai betű/szóolvasás és az alfabetikus/betűkre vonatkozó ismeret, kölcsönös viszonyban állnak a fonológiai tudatossággal, befolyásoló erővel bírnak a szóolvasó és a későbbi fluens olvasási készség fejlődésében. A betűkre vonatkozó ismeretek segítik a gyerekeket, hogy megértsék azt, hogy a szavak fonémákból épülnek fel. Az ismeretek bővülésével a fonológiai tudatosság is fejlődik, amely hozzájárul a szavak fonológiai egységekre való bontásához. Negyedik évfolyam végére e készségek fejlettsége biztosítja az olvasáskészség tanításának alapjait, amely a hatékony szövegértés elengedhetetlen eszköze (SÉNÉCHAL, 2011). 


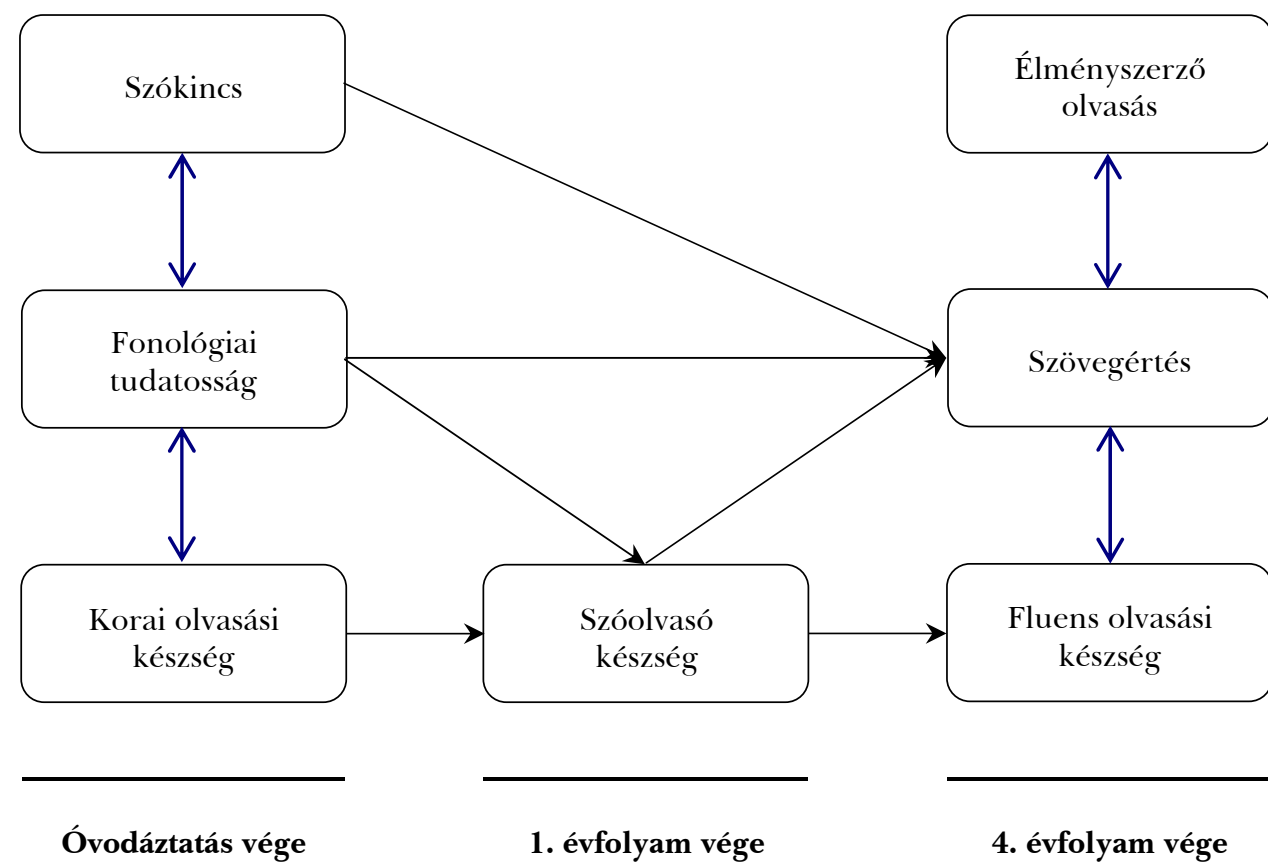

1. ábra. A fonológiai tudatosság szerepe az olvasástanulás időszakában (SÉNÉCHAL, 2011 alapján)

\section{A fonológiai tudatosság, szövegértés és a szocioökonómiai státusz kapcsolata}

A szülő iskolai végzettségéből, foglalkozásából és jövedelméből kalkulált szocioökonómiai index erős jóslója a gyermekek olvasásteljesítményének mind a dekódolást, mind az értő olvasást tekintve. A magasabb szocioökonómiai státuszhoz magasabb teljesítmény, míg az alacsonyabb szocioökonómiai státuszhoz alacsonyabb teljesítmény társul (Noble, Wolmetz, OCHS, FARAH és MCCANDliss, 2006).

TÓTH és CsÉPE (2008) szerint a szocioökonómiai háttér valóban hatással lehet a kognitív alapkészségek és olvasás kapcsolatára. NOBLE, FARAH és MCCANDLISS (2006) adataira hivatkozva kiemelik, hogy ebben a kapcsolatrendszerben a magas szocioökonómiai háttér „egyfajta védőfaktorként funkcionál”, amelynek lényege, hogy a magas szocioökonómiai családban élő gyermekek akkor is viszonylag jó olvasásteljesítményt nyújtanak, ha a fonológiai tudatosságban gyengeségek mutatkoznak (TÓTH és CSÉPE, 2008). VlOEDGRAVEN (2008) is vizsgálta a háttértényezők befolyását a fonológiai tudatosság fejlődésében. Eredményei megerősítik NOBLE, FARAH és MCCANDLISS (2006) kutatását, miszerint azok a gyerekek teljesítettek jól, akiknek a családja jó szocioökonómia helyzettel rendelkezett. Akik gyengébben teljesítettek, azoknak a szülei alacsonyabb iskolai végzettséget szereztek. 
Ezt támasztja alá LUNDBERG, LARMAN és STRID (2012) fonológiai tudatosságot fejlesztő kísérletének eredménye is. A fejlesztés célja az volt, hogy játékosan fejlesszék a fonológiai tudatosságot az iskolát megelőző évben. A kutatásuk során arra a kérdésre is keresték a választ, hogy a tudatosságot mennyire befolyásolja a nem és a család szocioökonómiai státusza. Az eredményeik szerint a fejlesztést megelőzően és azt követően a jobb helyzetben lévők továbbra is jobban teljesítettek, és azok számára volt hasznos a program, akik fejlettségben nem érték el a koruknak megfelelő fejlettségi szintet. A nemet tekintve a lányok teljesítettek jobban a fiúknál. Hecht, BuRgESs, TORgESEN, Wagnes és RASHOTTE (2000) longitudinális vizsgálatot végeztek az iskolát megelőző évtől kezdődően negyedik évfolyamig, és arra keresték a választ, hogy milyen szerepet játszanak a szociális különbségek az olvasással kapcsolatos képességek alakulásában, így a fonológiai tudatosságéban is. Az eredményeik alapján az iskolát megelőző évben a SES nem okoz különbségeket, hatása első évfolyamtól mérhető.

\section{A kutatás célja és kérdései}

A kutatás célja a fonológiai tudatosság fejlődésének és szövegértéssel való kapcsolatának feltárása az általános iskola első négy évfolyamán és a szocioökonómiai státusz szerepének vizsgálata e két képesség alakulásában. Az eddigi vizsgálatok eredményei alapján a következő kutatási kérdéseket fogalmaztuk meg:

1. Hogyan fejlődik a fonológiai tudatosság és annak egyes területei az általános iskola első négy évfolyamán?

2. Milyen kapcsolat van a fonológiai tudatosság fejlettsége és a család szocioökonómiai státusza között?

3. Milyen kapcsolat van a szövegértés és a család szocioökönómiai státusza között?

4. Milyen kapcsolatrendszer áll fenn a szocioökonómiai státusz, a fonológiai tudatosság és a szövegértés között?

\section{MÓDSZEREK}

\section{Minta}

A vizsgálatban egy megyeszékhelyen lévő általános iskola első négy évfolyamának tanulói $(\mathrm{N}=205)$ vettek részt. A minta eloszlását évfolyam tekintetében és az egyes évfolyamok átlagéletkorát és szórását az 1. táblázat tartalmazza. 
1. táblázat. A vizsgálatban részt vevők eloszlása évfolyamom és életkor tekintetében

\begin{tabular}{|c|c|c|}
\hline Évfolyam & $\begin{array}{c}\text { Elemszám } \\
(\mathrm{N})\end{array}$ & $\begin{array}{c}\text { Átlagéletkor } \\
\text { (Szórás) }\end{array}$ \\
\hline 1. & 47 & $7,77(0,48)$ \\
\hline 2. & 49 & $8,76(0,51)$ \\
\hline 3. & 52 & $9,79(0,59)$ \\
\hline 4. & 57 & $10,69(0,78)$ \\
\hline Összesen & 205 & $9,31(1,24)$ \\
\hline
\end{tabular}

\section{Méröeszközök}

Kutatásunk során három mérőeszközt használtunk: egy fonológiai tudatosság tesztet, egy szövegértés tesztet és egy háttérkérdőívet.

\section{Fonológiai tudatosság teszt}

A fonológiai tudatosságot mérő teszt négy résztesztből épül fel: 1. szótagszegmentálás, 2. rímfelismerés, 3. beszédhang-szegmentálás, 4. fonémaazonosítás (KISs és PATAI, 2015). A területek mérésére szolgáló feladatokat és reprezentatív példákat a 2. táblázat mutatja be. A célszavak szóban hangzottak el. A szavak a Magyar Nemzeti Szövegtárból lettek választva, az előfordulási gyakoriságuk egymillió szóban 1,53 és 5,41. A fonémaazonosítás feladat 16 itemet, a többi feladat 10-10 itemet tartalmazott. A szótagszegmentálás feladat 5 álszót és 5 létező szót tartalmazott (Hoffmann, Németh, Irinyi, PÁkÁski és Kálmán, 2009). A területet mérő feladatok előtt a tanulók kipróbálhatták az adott feladattípust, így csökkentve az új adatfelvételi médium használatához kapcsolódó készségek fejlettségi szintjének tanulói teljesítményre gyakorolt hatását. A teszt jó megbízhatósági mutatókkal rendelkezik mind összteszt (Cronbach- $\alpha=0,87$ ), mind az egyes szubtesztek szintjén.

2. táblázat. A fonológiai tudatosságot mérő feladatok és példák

\begin{tabular}{|l|l|}
\hline \multicolumn{1}{|c|}{ T e r ü l e t } & \multicolumn{1}{c|}{ F e l a d a t - p é l d a } \\
\hline Szótagszegmentálás & $\begin{array}{l}\text { A mese szóra kettőt tapsolunk: me (taps)-se (taps). } \\
\text { Hányat kell tapsolni a következő szóra? [kosár] }\end{array}$ \\
\hline Rímfelismerés & $\begin{array}{l}\text { a) Két szót fogsz hallani, rímelnek-e? [gén]-[méz] } \\
\text { b) Rímeket keresünk. Hallani fogsz egy szót, majd hármat. } \\
\text { Döntsd el, melyik rímel az elsővel. } \\
\text { [kór] - pók, pult toll }\end{array}$ \\
\hline Beszédhang-szegmentálás & Hány hang van a szóban? [nadrág] \\
\hline \multirow{3}{*}{ Fonémaazonosítás } & $\begin{array}{l}\text { a) A szó elején, közepén vagy végén hallod a következő } \\
\text { hangot? [r] - repülő }\end{array}$ \\
& b) Melyik szóban hallod a hangot? [k] - csiga, szakács
\end{tabular}


Szövegértés teszt

A tanulók szövegértését egy három szubtesztből álló mérőeszközzel vizsgáltuk. A három szubteszt - a hazai és nemzetközi nagymintás mérések tartalmi és mérési kereteivel összhangban - egy folyamatos (27 item), egy kevert (22 item) és egy nem folyamatos (15 item) formátumú szöveget és ahhoz kapcsolódó feladatokat tartalmazott. A szövegekhez tartozó feladatok a tanulók különböző olvasási műveletek elvégzésében nyújtott teljesítményét mérték: 1. információ-visszakeresés, 2. értelmezés és 3. reflexió. Az olvasási múveletek azonos arányban szerepeltek minden szubtesztben. A szövegértés teszt jó megbízhatósági mutatókkal rendelkezik összteszt és szubteszt szinten is (Cronbach- $\alpha=0,89$ ).

\section{Háttérkérdőí}

A tanulói teljesítményt befolyásoló tényezők feltárása egy papíralapú háttérkérdőívvel történt. Információt gyüjtöttünk a tanulók személyi adatairól, valamint a szülők iskolai végzettségéről. Jelen tanulmány keretein belül a család, illetve a tanulók szocioökonómiai státuszának jellemzésére az anya és apa iskolai végzettségéből származtatott képzett változót alkalmaztunk (ACARA, 2012). A képzett változó a két szülő iskolai végzettsége közül a magasabb értékét vette fel.

A szülők iskolai végzettségét hétfokú skálával írtuk le 1 . nem fejezte be az általános iskolát, 2. általános iskola, 3. szakiskola, szakmunkásképző, 4. érettségi, 5. föiskola (felsőfokú alapképzés), 6. egyetem (felsőfokú mesterképzés) és 7. doktori fokozat. Jelen kutatásban a szülők 6,8\%-a rendelkezett általános iskolai végzettséggel, 22\%-a szakiskolai vagy szakmunkásképző intézményben szerzett bizonyítványt, 27,3\%-a tett érettségi vizsgát, 19,5\%-a föiskolai, míg 24,4\%-a egyetemi diplomát szerzett. A vizsgált mintában az általános iskolát be nem fejező és doktori fokozattal rendelkező szülő nem volt.

\section{Eljárás}

Az adatfelvétel 2014. februártól május végéig tartott. A tanulók az online teszteket az eDia platformon keresztül 45 perces tanórák keretében oldották meg. A kitöltés, amelyet az iskolában tanító pedagógusok, illetve adatfelvételi biztosok felügyeltek, átlagosan három tanórát vett igénybe. A háttérkérdőívet a tanulók otthon töltötték ki szülői segítséggel. Minden tanuló ugyanazt a tesztet töltötte ki. A tesztek kizárólag zárt itemeket tartalmaztak. 


\section{EREDMÉNYEK}

\section{A fonológiai tudatosság alakulása 1-4. évfolyamon}

A tanulók teljes fonológiai tudatosság teszten elért eredményeit évfolyamonkénti bontásban a 2. ábra szemlélteti. Az egyszempontos varianciaelemzésből kapott adatok alapján elmondható, hogy az első és második évfolyamos tanulók teljesítménye nem különbözik szignifikánsan, azonban e két évfolyamon a harmadik és negyedik évfolyamhoz viszonyítva szignifikánsan alacsonyabb tesztpontszámot értek el $(\mathrm{F}(3,201)=22,39 p<0,01)$. A harmadikosok és negyedikesek összteszten elért pontszáma statisztikailag nem különbözik.

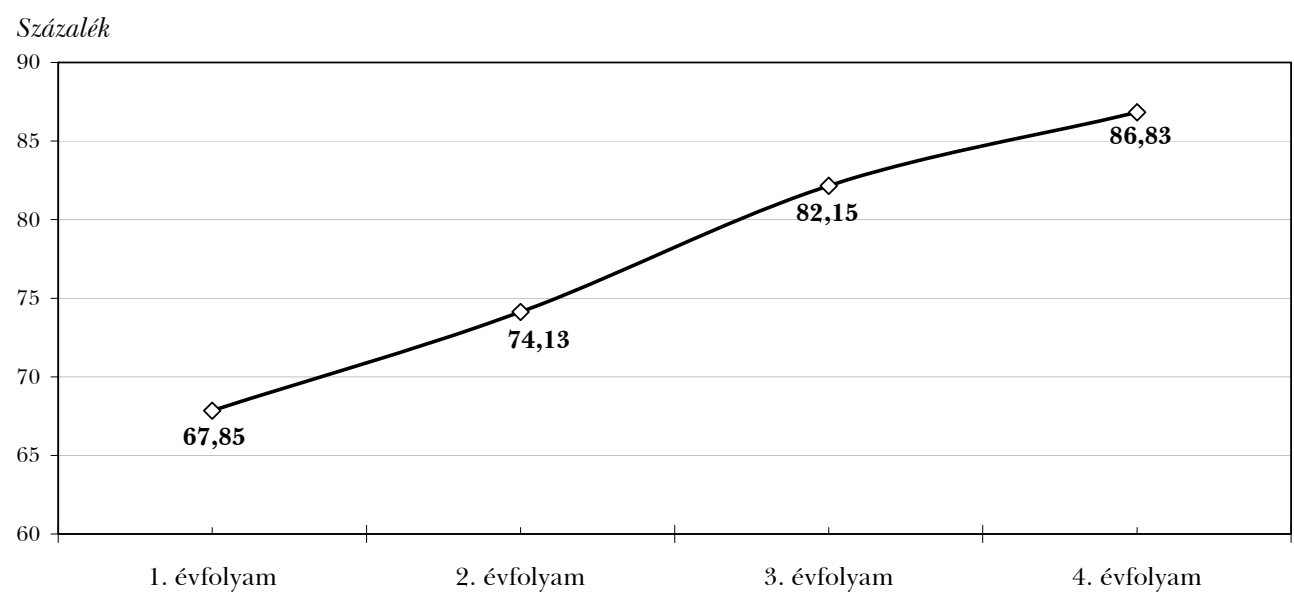

2. ábra. A fonológiai tudatosság teszten elért eredmények évfolyamonként

Az egyes területeket tekintve eltérő fejlődési tendenciára következtethetünk (3. ábra). A szótagszegmentálás esetében az első és harmadik között mért teljesítménykülönbségek szignifikánsak. Ezzel ellentétben a harmadik és negyedik évfolyam közötti tanulói teljesítmények között nem találtunk szignifikáns eltérést $(\mathrm{F}(3,201)=10,04 p<0,01)$. A rímfelismerés és a fonémaazonosítás területeinél hasonló változás következik be, mint a szótagszegmentálásnál (Frím(3,201)=14,28 $p<0,01 ; \operatorname{Ffonaz}(3,201)=23,73 p<0,01)$. A beszédhang-szegmentálásnál az egyes évfolyamok közötti teljesítménybeli különbségek statisztikailag nem különböztek $(\mathrm{F}(3,201)=1,51 p>0,05)$.

A területek évfolyamon belüli vizsgálatához két szempontos vegyes varianciaelemzést végeztünk. Az elemzés eredményei azt mutatják, hogy a tanulók a rímfelismerésen a többi területhez viszonyítva szignifikánsan alacsonyabban teljesítettek minden évfolyamon $(\mathrm{F}(3,199)=35,01, p<0,01$; Pillai's Trace $=0,35)$, a szótagszegmentálást mérő feladatokon nyújtott teljesítmény pedig minden más területnél szignifikánsan magasabb volt az első kivételével minden évfolyamon 


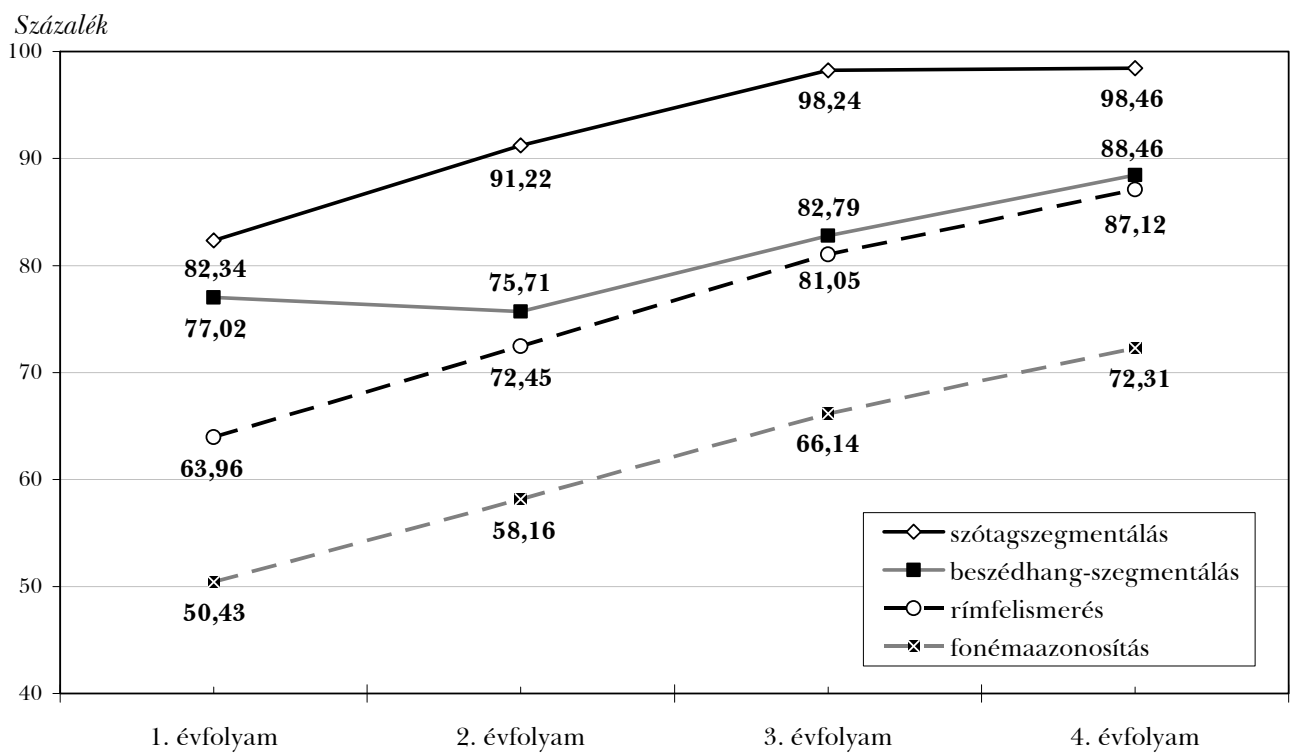

3. ábra. A fonológiai tudatosság egyes területeken elért teljesítmény évfolyamonként

$(\mathrm{F}(3,199)=33,23, p<0,01$; Pillai's Trace $=0,33)$. Az első évfolyamos tanulók szignifikánsan alacsonyabban teljesítettek a fonémaazonosításon szótagszegmentálás és beszédhang-szegmentálás területéhez viszonyítva, viszont ez utóbbi két terület között nem volt jelentős a különbség. A második évfolyam esetében már a beszédhang-szegmentálás és a fonémaazonosítás között nem volt statisztikailag különbség, és ez a kép rajzolódik ki a harmadik és a negyedik évfolyamnál is $(\mathrm{F}(3,199) \mathrm{bszeg}=38,36, p<0,01 ;$ Pillai's Tracebszeg $=0,37 ; \mathrm{F}(3,199)$ fonaz $=23,65$, $p<0,01$; Pillai's Tracefonaz $=0,26$ ).

\section{A szocioökonómiai státusz kapcsolata a fonológiai tudatosság és a szövegértés fejlettségével}

A tanulók fonológiai tudatosság teszten nyújtott teljesítménye mérsékelt, de szignifikáns összefüggést mutatott a szocioökonómiai státusszal (3. táblázat). A fonológiai tudatosság területek közül leginkább a fonémaazonosítás és legkevésbé a beszédhang-szegmentálás függött össze a SES-szel. A fonológiai tudatosság többi részterületét tekintve számértékében közel hasonló alacsony korrelációs értékeket találunk. A szövegértés és a SES közötti kapcsolat mértékét tekintve hasonló korrelációs összefüggés mutatkozott, mint a fonológiai tudatosság esetében. A különböző szövegformátumokat reprezentáló részteszteket tekintve a szülők iskolai végzettsége leginkább a folyamatos szövegen nyújtott teljesítménnyel függött össze, míg a kevert és a nem folyamatos szöveg esetében közel azonos mértékű, gyenge korrelációs értékeket kaptunk. 
3. táblázat. A SES összefüggése a fonológiai tudatossággal és szövegértéssel teljes teszt és részteszt szerinti bontásban

\begin{tabular}{|c|c|c|c|}
\hline Ter ület & $\begin{array}{c}\text { Szocioökonómiai } \\
\text { státusz }\end{array}$ & Részteszt & $\begin{array}{c}\text { Szocioökonómiai } \\
\text { státusz }\end{array}$ \\
\hline Szótagszegmentálás & $0,25^{* *}$ & \multirow[b]{2}{*}{ Folyamatos } & \\
\hline Rímfelismerés & $0,29^{* * *}$ & & $0,38^{* *}$ \\
\hline Beszédhang-szegmentálás & $0,16^{*}$ & Kevert & $0,33^{* *}$ \\
\hline Fonémaazonosítás & $0,40^{* *}$ & Nem folyamatos & $0,35^{* *}$ \\
\hline $\begin{array}{l}\text { Fonológiai tudatosság } \\
\text { Teljes teszt }\end{array}$ & $0,41^{* *}$ & $\begin{array}{l}\text { Szövegértés } \\
\text { teljes teszt }\end{array}$ & $0,41^{* *}$ \\
\hline
\end{tabular}

"Szignifikáns $p<0,05 ;{ }^{* *}$ Szignifikáns $p<0,01$

A SES és a fonológiai tudatosság között lévő összefüggés jobb megértéséhez első lépésként tercilisekre osztottuk a mintánkat az összevont SES-változó alapján. Jelen esetben az első tercilist az érettségivel nem rendelkező szülők alkotják $(\mathrm{N}=59)$, a másodikat az érettségivel rendelkezők $(\mathrm{N}=56)$, míg a harmadik tercilisbe a felsőfokú végzettséggel rendelkező szülők kerültek $(\mathrm{N}=90)$. A következő lépésként egy szempontos MANOVA-t végeztünk. Eredményeink szerint szignifikáns különbség mutatkozott a szövegértés és a fonológiai tudatosság teljesítményben a család szocioökonómiai státusza szerint $(\mathrm{F}(4,400)=10,50 \quad p<0,01$; Wilk's $\Lambda=0,82$, partial $\left.\eta^{2}=0,09\right)$. Az érettségi hiánya és megléte nem okozott

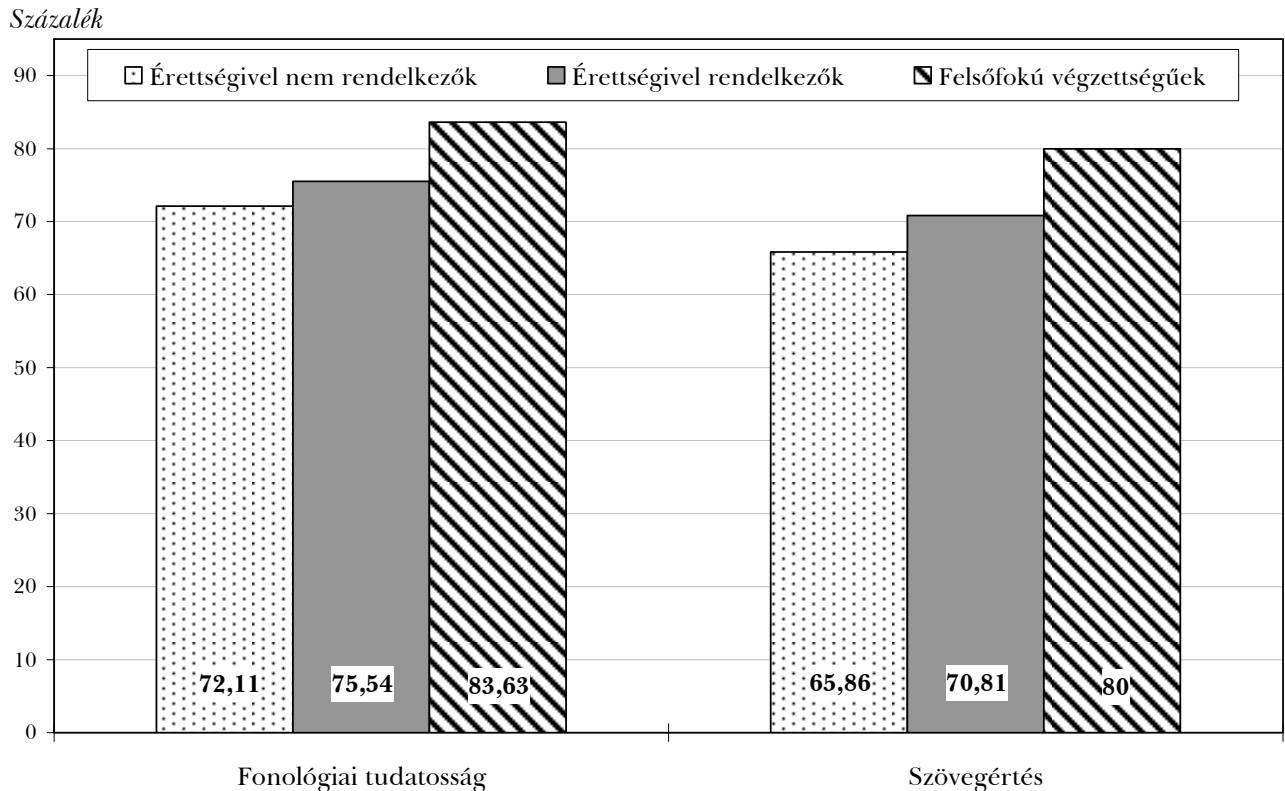

4. ábra. A fonológiai tudatosság és a szövegértési teljesítmény a SES-tercilisek alapján 
szignifikáns teljesítménykülönbséget, viszont a felsőfokú végzettségủ szülők gyermekei magasabb pontszámot értek el a fonológiai tudatossági és a szövegértési teszten a másik két tercilishez viszonyítva. Azok a gyerekek, akiknek a szülei felsőfokú iskolai végzettséggel rendelkeznek, azok magasabb teljesítettek a többi tanulóhoz viszonyítva (4. ábra).

A negyedik kutatási kérdés megválaszolásához strukturális egyenletek modellt készítettünk (NATiOn és SNOWLING, 2004; KJELDSEN és mtsai, 2014; SÉNÉCHAL, 2011). Az elméleti háttérben leírtak alapján feltételeztük, hogy a SES befolyásolja mind a fonológiai tudatosság mind a szövegértés alakulását, valamint, hogy a két kognitív változó között összefüggés van.

A modellt és az elemzés eredményeit az 5 . ábra szemlélteti. A modell megfelelő illeszkedési mutatókkal rendelkezik $\left(\chi^{2}=30,27, \mathrm{df}=24, p>0,05 ; \mathrm{RMSEA}=.03\right.$;

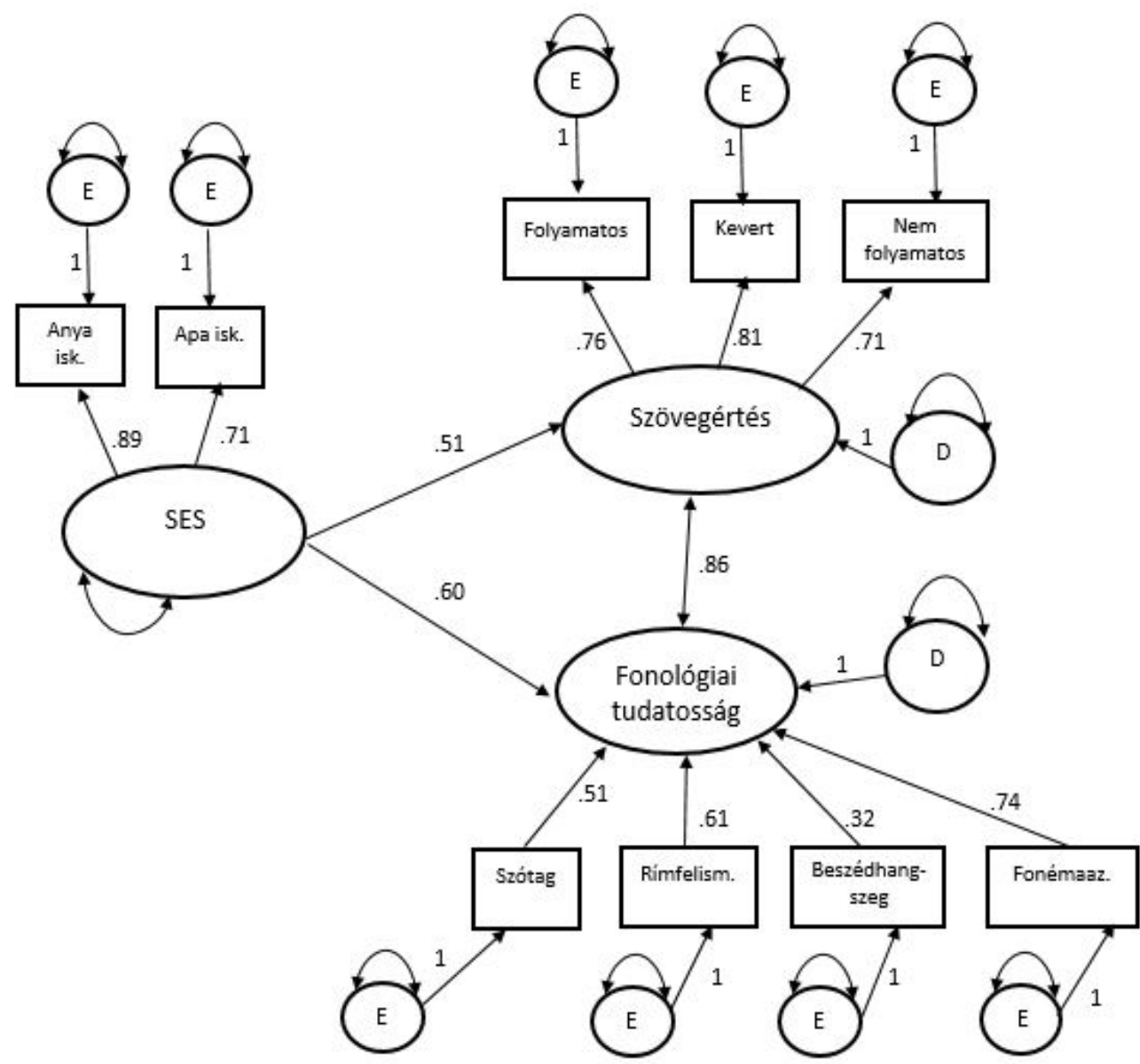


$\mathrm{CFI}=.99 ; \mathrm{TLI}=.98 ; \mathrm{SRMR}=.03)$. A modellben latens változóként szerepeltettük a szövegértést, a fonológiai tudatosságot és a szocioökonómiai státuszt. Az eredmények alapján a mért változók jól meghatározzák a három latens változót. Az ábra szerint a SES meghatározza a fonológiai tudatosság és a szövegértés teljesítményt, illetve e két kognitív változó között kölcsönös kapcsolat van.

\section{KÖVETKEZTETÉSEK ÉS ÖSSZEGZÉS}

Az elmúlt évtizedekben számos külföldi kutatási eredmény mutatott rá a fonológiai tudatosság olvasásban betöltött kiemelt szerepére. Ennek megfelelően a fonológiai tudatosság fejlődésére és az azt befolyásoló tényezők feltárására irányuló vizsgálatok száma is nagymértékben megnőtt. Bár a vonatkozó szakirodalmak tanulsága szerint hazai színtéren is egyhangúan elismerik e metakognitív készség fontosságát és jelen tanulmány elkészítéséhez kiváló inspirációul szolgáltak, az eddig folytatott magyar nyelvre vonatkozó empirikus kutatások nem fedtek le sok potenciálisan érintett életkori szakaszt, a fonológiai tudatosság konstruktumát változó összetétellel definiálták, valamint a fejlődést befolyásoló háttérváltozók vizsgálata is alulreprezentáltnak mondható. Emellett tudomásunk szerint a fonológiai tudatosság szövegértéssel való kapcsolatát az olvasástanulás teljes időszakában feltáró vizsgálat még hiányzik a hazai tudományos palettáról. Jelen tanulmány keretében arra kerestük a választ, hogy 1 . hogyan alakul a fonológiai tudatosság fejlődése az általános iskola első négy évfolyamán az olvasástanulás időszakában a magyar mint sekély ortográfiájú, transzparens nyelv esetében, 2. milyen mértékben befolyásolja a szülők iskolai végzettségével reprezentált szocioökonómiai státusz a fonológiai tudatosságot és a szövegértés teljesítményt, illetve 3. milyen kapcsolat mutatható ki a három változó között.

A tanulók fonológiai tudatosság összpontszámai azt mutatják, hogy a fonológiai tudatosság fejlettségi szintjében szignifikáns változás második és harmadik évfolyam között történik és a teljesítmény még a negyedik évfolyamon sem éri el a maximumot. Ez ellentmond azoknak a sekély ortográfiájú nyelvekre vonatkozó nemzetközi eredményeknek, amelyek szerint a képesség fejlettsége a második évfolyam végére éri el az optimum szintet. Adataink alátámasztják a fonológiai tudatosság diagnosztikus mérésének és fejlesztésének létjogosultságát a felsőbb évfolyamokon is. Sajnálatos tény azonban, hogy a fluens olvasás alapjainak fejlesztésére a magyar közoktatás keretein belül csak az alsó négy évfolyamon s ott is csak korlátozott óraszámban van lehetőség. E problémára a rendszerszintű mérések eredményei alapján megfogalmazott ajánlások rendszeresen rávilágítanak.

A részkészségek fejlődése tekintetében elmondható, hogy a tesztben vizsgált területek közül a tanulók fonémaazonosítás, szótagszegmentálás és rímfelismerés teljesítményében az első három évfolyam között volt szignifikáns különbség, azaz feltehetőleg a fejlődés is ebben a periódusban történik. A beszédhang-szegmentálás esetében nem volt statisztikailag kimutatható a változás a négy évfolyam között. Ez köszönhető annak is, hogy a tanulók már viszonylag magas teljesítményt értek el első évfolyamon is és ez a szint megmaradt a későbbiekben is. 
A tanulók a szótagszegmentálás területén szignifikánsan magasabb pontszámot értek el a többi területhez viszonyítva a vizsgált évfolyamok mindegyikén, amely arra utal, hogy ez könnyű feladatnak bizonyult számukra. Ezzel szemben a rímfelismerés alacsony pontszámai azt mutatják, hogy ehhez a részkészséghez kapcsolódó feladatok nehézséget okoztak a tanulóknak. A beszédhang-szegmentálás és a fonémaazonosítás területein elért teljesítmény között második évfolyamtól kezdve nem volt statisztikailag kimutatható különbség. Jelen vizsgálatban a szótagokkal és a fonémákkal kapcsolatos mủveleteken magasabb teljesítményt értek el a tanulók a rímfelismeréshez képest. A szakirodalom szerint a fejlődés a tágabb nyelvi egységektől a szűkebb egységek felé történik, viszont eredményeink nem támasztják alá ezt az univerzálisnak tekinthető nézetet (DUNCAN, 2010). Mindazonáltal a feladat nehézsége befolyásolta a tanulók rímmel kapcsolatos eredményét, ezért további vizsgálatok szükségesek a fejlődéssel kapcsolatos következtetések levonásához. Azonban az eredmények alapul szolgálhatnak gyakorló pedagógusok számára a korosztályokhoz kötött fejlesztési pontok kijelölésében.

A szocioökonómiai státusz szövegértéssel való kapcsolatára a nagymintás rendszerszintű mérések rendszeresen rámutatnak. Az adatok szerint az alacsony és magas szocioökonómiai családi háttérrel rendelkező gyermekek teljesítménye közötti különbség igen jelentős (például JENkins, MickLEWRight és SCHNEPF, 2008; OECD, 2010), és ez óriási kihívás elé állítja a pedagógusokat, kutatókat és döntéshozatalban érintetteket egyaránt. További nehézséget jelent, hogy azon gyermekek, akik az olvasástechnikát megalapozó készségek tekintetében nem képesek elérni egy optimális fejlettségi szintet a közoktatás keretében zajló célzott fejlesztés ellenére sem, komoly akadályokkal kell szembenéznie a dekódolás és az értő olvasás során is. Adataink rámutatnak, hogy a család szocioökonómiai státusza befolyásolja a szövegértés és a fonológiai tudatosság alakulását egyaránt, és ez utóbbi két változó kölcsönösen meghatározza egymást. Többváltozós elemzéseink szerint a szülők felsőfokú végzettsége előnyt jelent a gyermekek számára a fonológiai tudatosság és a szövegértés fejlődése során. Ennek oka valószínűleg az, hogy a magas szocioökonómiai családi háttérrel rendelkező gyermekek nagyobb mértékben jutnak az írásbeliségüket, kognitív fejlődésüket elősegítő eszközökhöz, tevékenységekhez és tapasztalatokhoz. A szülők iskolai végzettsége mellett meghatározó tényezőkként tartják számon a jövedelmi szintet, a szülők időfelhasználásában mutatkozó eltéréseket, a családdal végzett közös tevékenységek és a szülő-gyermek interakciók eltérő minőségét és mennyiségét, valamint a könyvekhez való hozzáférés mértékét (KERTESI és KÉZDI, 2012). Tehát eredményeink azt sugallják, hogy a szocioökonómiai státusz befolyásolja az olvasás egyik meghatározó előkészségének fejlettségi szintjét, amelynek bizonyos részkészségei már jóval a formális oktatás megkezdése előtt spontán fejlődnek, így ismételten megerősítik az igényt a kora gyermekkori megelőzésre és fejlesztésre.

Jelen vizsgálat korlátai - amelyek egyúttal a vizsgálat további irányait is kijelölik - legalább három fő pont köré rendezhetők. Egyrészről a fonológiai tudatosság egyes elemei már spontánul, a nyelvi fejlődés korábbi szakaszaiban is megjelennek, így a vizsgálat óvodáskorú gyermekekre történő kiterjesztése pontosabb képet adhat a fonológiai tudatosság fejlődéséről, illetve árnyalhatja a fejlődés tekin- 
tetében levont következtetéseket, különös tekintettel az egyes szintek, részterületek fejlődési tendenciáira. Másrészről a saját fejlesztésű online fonológiai tudatosság mérőeszközünkben a feladat megoldásához szükséges műveleteket tekintve tesztünkben elsősorban a szó különböző méretű belső egységeinek a szegmentálása és azonosítása dominált, bár KILPATRICK (2012) szerint a mérőeszközök manipulációt és szintézist igénylő itemekkel történő kiegészítése kívánatos, mert azok jobban magyarázzák a tanulók olvasásteljesítményének varianciáját. Továbbá a vizsgálat mérőeszközeinek az olvasási képesség több kulcskomponensére kiterjedő bővítése célravezető lenne a fonológiai tudatosság direkt és indirekt hatásainak meghatározása, illetve SÉNÉCHAL (2011) modelljének magyar nyelvben történő tesztelése érdekében.

Összességében a fentiek alapján arra következtethetünk, hogy a fonológiai tudatosság nem csak a dekódolásban, hanem az értő olvasásban is szerepet játszik, így a fonológiai tudatosság rendszeres, hatékony és korai fejlesztése hozzájárulhat a tanulók szövegértési teljesítményének javulásához. A kedvezőtlen családi körülmények kognitív teljesítményekben mért negatív hatásának kiküszöbölésére megoldást jelenthet a hároméves kortól kötelező óvodáztatás és a problémás területek korai beazonosítása, fejlesztése.

\section{MELLÉKLET}

4. táblázat. A vizsgált változók közötti összefüggések (Spearman-korreláció)

\begin{tabular}{|c|c|c|c|c|c|c|c|c|}
\hline & 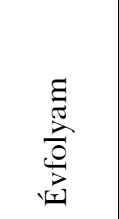 & 乑 & 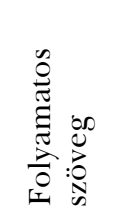 & 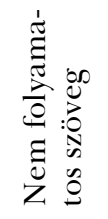 & 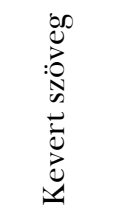 & 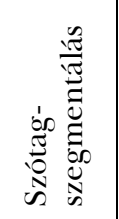 & 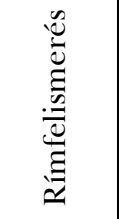 & 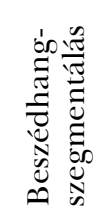 \\
\hline SES & $0,441^{* *}$ & & & & & & & \\
\hline Folyamatos szöveg & $0,552^{* *}$ & $0,383^{* *}$ & & & & & & \\
\hline Nem folyamatos szöveg & $0,590^{* *}$ & $0,347^{* *}$ & $0,508^{* *}$ & & & & & \\
\hline Kevert szöveg & $0,584^{* *}$ & $0,334^{* *}$ & $0,633^{* *}$ & $0,594^{* *}$ & & & & \\
\hline Szótagszegmentálás & $0,344^{* *}$ & $0,245^{* *}$ & $0,388^{* *}$ & $0,370^{* *}$ & $0,347^{* *}$ & & & \\
\hline Rímfelismerés & $0,416^{* *}$ & $0,285^{* *}$ & $0,396^{* *}$ & $0,454^{* *}$ & $0,446^{* *}$ & $0,263^{* *}$ & & \\
\hline Beszédhang-szegmentálás & $0,187^{* *}$ & $0,159^{*}$ & $0,288^{* *}$ & 0,127 & $0,202^{* *}$ & $0,250^{* *}$ & $0,186^{* *}$ & \\
\hline Fonémaazonosítás & $0,550^{* *}$ & $0,400^{* *}$ & $0,498^{* *}$ & $0,468^{* *}$ & $0,526^{* *}$ & $0,363^{* *}$ & $0,471^{* *}$ & $0,243^{* *}$ \\
\hline
\end{tabular}




\section{IRODALOM}

ACARA (2012). Data standards manual: Student background characteristics. Sydney: ACARA.

AdAMIKNÉ JÁszó A. (2003). Csak az ember olvas: az olvasás tanítása és lélektana. Budapest: Tinta Könyvkiadó.

Anthony, J. L., \& Francis, D. J. (2005). Development of phonological awareness. Current Directions in Psychological Science, 14(5), 255-259.

Blomert, L. és CsÉPE V. (2012). Az olvasástanulás és -mérés pszichológiai alapjai. In CsAPó B. és CséPe V. (szerk.), Tartalmi keretek az olvasás diagnosztikus értékeléséhez (17-85). Budapest: Nemzeti Tankönyvkiadó.

Carroll, J. M, Snowling, M. J., Hulme, C., \& Stevenson, J. (2003). The development of phonological awareness in preschool children. Developmental Psychology, 39(5), 913-923.

CsÉPE V. (2006). Az olvasó agy. Budapest: Akadémiai Kiadó.

Duncan, L. G. (2010). Phonological development from a cross-linguistic perspective. In N. Brunswick, S. McDougall, \& D. P. DE Mornay (Eds.), Reading and dyslexia in different orthographies (43-68). New York: Psychology Press.

Ehri, L. C., Nunes, S. R., Willows, D. M., Schuster, B. V., Yaghoub-Zadeh, Z., \& Shanahan, T. (2001). Phonemic awareness instruction helps children learn to read: evidence from the National Reading Panel's meta-analysis. Reading Research Quarterly, 36(3), 250-287.

Furnes, B., \& SAmuelsson, S. (2011). Phonological awareness and rapid automatized naming predicting early development in reading and spelling: Results from a crosslinguistic longitudinal study. Learning and Individual differences, 21(1), 85-95.

Goswami, U., \& Bryant, P. (1990). Phonological Skills and Learning to Read. London: Lawrence Erlbaum Associates.

Hecht, S. A., Burgess, S. R., Torgesen, J. K., Wagnes, R. K., \& Rashotte, C. A. (2000). Explaining social class differences in growth of reading skills from beginning kindergarten through fourth-grade: The role of phonological awareness, rate of access and print knowledge. Reading and writing, 12(1-2), 99-127.

Hoffmann I., Németh D., Irinyi T., PÁkÁski M. és Kálmán J. (2009). Verbális munkamemória és a fonológiai rövid távú emlékezet működése Alzheimer-kórban. Nyelvtudományi Közlemények, 106, 242-257.

JORDANIDISZ Á. (2009). A fonológiai tudatosság fejlődés az olvasástanulás időszakában. Anyanyelv-pedagógia, 2(4). http://anyanyelv-pedagogia.hu/cikkek.php?id=222

Jenkins, S. P., Micklewright, J., \& SChnepf, S. V. (2008). Social segregation in secondary schools: How does England compare with other countries? Oxford Review of Education, 34(1), 21-38.

JózsA K. és STEkLÁcs J. (2009). Az olvasástanulás kutatásának aktuális kérdései. Magyar Pedagógiai, 109(4), 365-397.

KASSAI I. (1999). Szótagtudat és olvasástanulás. In KASSAI I. (szerk.), Szótagfogalom - szótagrealizációk (153-165). Budapest: MTA Nyelvtudományi Intézet.

Kertesi G. és KézDi G. (2012). A roma és nem roma tanulók teszteredményei közti különbségekről és e különbségek okairól. Közgazdasági Szemle, 59(7-8), 798-853.

Kiss R. és PATAI J. (2015). A korai olvasási képességek mérése 4-8 éves gyermekek körében. In KlipPel R., Sulyok H. és TóTH E. (szerk.), Nyelvek, kódok, hallgatók: Alkalmazott Nyelvészeti Tanulmányok 2. (40-44.) Szeged: Szegedi Egyetemi Kiadó-Juhász Gyula Felsőoktatási Kiadó. 
Kilpatrick, D. A. (2012). Phonological segmentation assessment is not enough: A comparison of three phonological awareness tests with first and second graders. Canadian Journal of School Psychology, 27(2), 150-165.

KJeldsen, A. C., Kärnä, A., Niemi, P., Olofsson, Å., \& Witting, K. (2014). Gains From Training in Phonological Awareness in Kindergarten Predict Reading Comprehension in Grade 9. Scientific Studies of Reading, 18(6), 452-467.

LundBerg, I., LARSMAN, P., \& STRID, A. (2012). Development of phonological awareness during the preschool year: the influence of gender and socio-economic status. Reading and writing, 25(2), 305-320.

McDowell, K. D., Lonigan, C. J., \& Goldstein, H. (2007). Relations among socioeconomic status, age, and predictors of phonological awareness. Journal of Speech, Language, and Hearing Research, 50(4), 1079-1092.

NAGY J. (2006). Olvasástanítás: a megoldás stratégiai kérdései. In JózSA K. (szerk.), Az olvasási képesség fejlődése és fejlesztése (17-42). Budapest: Dinasztia Tankönyvkiadó.

NATIOn, K., \& SNOWLing, M. J. (2004). Beyond phonological skills: broader language skills contribute to the development of reading. Journal of Research in Reading, 27(4), 342356.

Noble, K. G., Farah, M. J., \& McCandliss, B. D. (2006). Socioeconomic background moduletes cognition-achievement relationship in reading. Cognitive Development, 21(3), 349-368.

Noble, K. G., Wolmetz, M. E., Ochs, L. G., Farah, M. J., \& McCandliss, B. D. (2006). Brain-behavior relationships in reading acquisition are modulated by socioeconomic factors. Developmental science, 9(6), 642-654.

OECD (2010). PISA 2009 Results (Volume II): Overcoming social background - Equity in learning opportunities and outcomes. Paris: OECD.

Oulette, G. P., \& Haley, A. (2013). One complicated extended family: the influence of alphabetic knowledge and vocabulary on phonemic awareness. Journal of Research in Reading, 36(1), 29-41.

Phillips, B. M., \& Torgesen, J. K. (2006). Phonemic awareness and reading: Beyond the growth of initial reading accuracy. Handbook of early literacy research, 2, 101-112.

SÉNÉCHAL, M. (2011). A model of the concurrent and longitudinal relations between home literacy and child outcomes. Handbook of early literacy research, 3, 175-188.

SÉnÉChal, M., Ouellette, G., \& YounG, L. (2004). Testing the concurrent and predictive relations among articulation accuracy, speech perception, and phoneme awareness. Journal of Experimental Child Psychology, 89(3), 242-269.

SHANAHAN, T. (2012). Early literacy development: Sequence of acquisition (Rev., ed.). Encyclopedia of language and literacy development (1-7). London, ON: Western University. Letöltve: http://www.literacyencyclopedia.ca/pdfs/topic.php?topId=225

Skibbe, L. E., Grimm, K. J., Bowles, R. P., \& Morrison, F. J. (2012). Literacy growth in the academic year versus summer from preschool through second grade: differential effects of schooling across four skills. Scientific Studies of Reading, 16(2), 141-165.

TóTH D. (2012). Mit, miért, hogyan? Mérés és értelmezés a kognitív olvasásfejlödési vizsgálatokban. Doktori Értekezés. Budapest: Eötvös Lóránd Tudományegyetem Pedagógiai és Pszichológiai Kar.

Tóth D. és CsÉPE V. (2008). Az olvasás fejlődése kognitív pszichológiai nézőpontból. Pszichológia, 28(1), 35-52. 
Vaessen, A., Bertrand, D., Tóth, D., Csépe, V., Faisca, L., Reis, A., \& Blomert, L. (2010). Cognitive development of fluent word reading does not qualitatively differ between transparent and opaque orthographies. Journal of Educational Psychology, 102(4), $827-842$.

Vloedgraven, J. (2008). Development of phonological awareness in relation to literacy. An item response theory perspective. Kézirat. Nijmegen: Expertisecentrum Nederlands, Radboud Universiteit Nijmegen.

Wood, C. (2002). Parent-child pre-school activities can affect the development of literacy skills. Journal of Research in Reading, 25(3), 241-258.

Ziegler, J. C., \& Goswami, U. (2005). Reading acquistion, developmental dyslexia, and skilled reading arcoss languages: a psycholinguistic grain size theory. Psychological Bulletin, 131(1), 3-29.

Ziegler, J. C., Bertrand, D., Tóth, D., Csépe, V., Reis, A., Faísca, L., Saine, N., Lyytinen, H., Vaessen, A., \& Blomert, L. (2010). Orthographic depth and its impact on universal predictors of reading: A cross-language investigation. Psychological Science, 21(4), 551-559.

\title{
THE RELATIONSHIP BETWEEN THE DEVELOPMENT OF PHONOLOGICAL AWARENESS, READING COMPREHENSION AND SOCIOECONOMIC STATUS FROM GRADES 1 TO 4
}

\author{
TÖRÖK, TÍMEA - HÓDI, ÁGNES
}

Phonological awareness has been in the focus of much research as an important and reliable predictor of later reading ability. The majority of studies defined reading as word reading or decoding and less attention has been dedicated to comprehension. The few studies conducted in English using comprehension as a construct showed that there is a positive correlation between phonological awareness and reading comprehension that last over time. Mounting evidence shows that Hungarian students' reading achievement is influenced by their socioeconomic status to a great extent. The majority of researchers agree that this also holds true for phonological awareness. However, this has not been confirmed in a Hungarian environment. Therefore, the present study aims at examining the development of phonological awareness, the relationship between students' phonological awareness and reading comprehension achievement and the relationship between these variables and socioeconomic status.

205 elementary school students were administered an online phonological awareness test, a reading comprehension test and a paper-and-pencil background questionnaire.

As far as phonological awareness development is concerned, data showed a significant change in students' performance between Grades 2 and 3. However, it did not reach a peak at the end of Grade 4 either. Findings also lend support to the role of socioeconomic status in students' phonological awareness and reading comprehension achievement. Structural equation modeling revealed that socioeconomic status influences and predicts both reading comprehension and phonological awareness, and phonological awareness and reading comprehension are mutually related.

This study highlights the importance of targeted phonological awareness development and the compensation of environmental deficits during the period of learning to read.

Key words: $\quad$ phonological awareness, reading comprehension, socioeconomic status 